\title{
Assessment of natural radioactivity and radiation hazard in volcanic tuff stones used as building and decoration materials in the Cappadocia region, Turkey
}

\author{
M. DEGERLIER*
}

(Manuscript received 20 January 2012, accepted 20 September 2012)

ABSTRACT The concentrations of natural radionuclides in 6 different colors of volcanic tuff stones which are derived from the Cappadocia region in Turkey were determined using gamma-ray spectroscopy with a HPGe detector, and the mineralogical composition and formula of stones were determined by an X-ray powder diffractometer. The average activity concentrations of ${ }^{238} \mathrm{U},{ }^{232} \mathrm{Th}$ and ${ }^{40} \mathrm{~K}$ are 50.7 , 58.6 and 717.6 Bq. $\mathrm{kg}^{-1}$, which are higher than the world averages of 35,30 and $400 \mathrm{~Bq} \cdot \mathrm{kg}^{-1}$, respectively. The radium equivalent activities $\left(R a_{\mathrm{eq}}\right)$, external hazard index $\left(H_{\mathrm{ex}}\right)$, and internal hazard $\left(\boldsymbol{H}_{\mathrm{in}}\right)$ associated with the natural radionuclides, alpha $\left(I_{\sigma}\right)$ and gamma indices $\left(I_{\gamma}\right)$ were calculated to assess the radiation hazard of the natural radioactivity in the volcanic tuff stones. The average indoor annual effective dose equivalent is $0.1 \mathrm{mSv}$. All values of the indoor effective dose are lower than the exemption dose value of $0.3 \mathrm{mSv}$. The calculated radium equivalent activity values vary from $60.31 \mathrm{~Bq} \cdot \mathrm{kg}^{-1}$ to $281.32 \mathrm{~Bq} \cdot \mathrm{kg}^{-1}$ with a mean of $189.78 \mathrm{~Bq} \cdot \mathrm{kg}^{-1}$. All values of radium equivalent activity are lower than the world average. The average indoor absorbed dose rate $\left(D_{\text {in }}\right)$ for volcanic tuff stones, calculated to be 21.18 nGy.h $\mathrm{h}^{-1}$, is lower than the world average of $84 \mathrm{nGy} \cdot \mathrm{h}^{-1}$.

Keywords: natural radioactivity / radiation hazard / building materials / volcanic tuff stones

\section{Introduction}

Natural radioactivity is widespread in the earth's environment; it exists in soil, plants, water and air. Environmental natural gamma radiation is formed from terrestrial and cosmic sources (Merdanoglu and Altinsoy, 2006). Natural radiation is the largest contributor to the external dose of the world's population (UNSCEAR, 2000) These dose rates vary from one place to another depending upon the concentration of natural radionuclides such as ${ }^{238} \mathrm{U},{ }^{226} \mathrm{Ra},{ }^{232} \mathrm{Th}$ and ${ }^{40} \mathrm{~K}$ present in the soil (UNSCEAR, 1988).

Nevsehir University Science and Art Faculty Physics Department, Nevsehir, Turkey.

* e-mail: meltem.degerlier@lnl.infn.it 
Besides medical exposure and cosmic radiation, building materials containing naturally occurring radionuclides are the main source of exposure as well. Construction raw materials are products which are derived from rock, soil and industrial additives such as the products of phosphoric acid (phosphogypsum) and fly ash produced from power stations. In addition to the naturally occurring radioactivity in the soil and rocks, these building material additives also contain trace amounts of natural radionuclides knowledge of the natural radioactivity in these materials is important for determining the amount of public exposure because people spend most of their time (about 80\%) indoors (Al-Sulaiti et al., 2011; Stoulos et al., 2003).

Generally, the specific activities of ${ }^{238} \mathrm{U},{ }^{232} \mathrm{Th}$ and ${ }^{40} \mathrm{~K}$ in the building raw materials and their products mainly depend on geological and geographical conditions as well as the geochemical characteristics of those materials (Turhan, 2008; Baykara et al., 2011).

Internal exposure involves the inhalation of alpha particles emitted from the short-lived decay products of radon $\left({ }^{222} \mathrm{Rn}\right.$, the daughter product of $\left.{ }^{226} \mathrm{Ra}\right)$ and thoron $\left({ }^{220} \mathrm{Rn}\right.$, the daughter product of $\left.{ }^{224} \mathrm{Ra}\right)$.

The most important source of external radiation exposure in buildings is caused by the gamma rays emitted from members of the uranium and thorium decay chains and from ${ }^{40} \mathrm{~K}$ occurring naturally in building materials.

The building materials in large buildings made of brick, concrete or stone act as attenuators of gamma rays emitted outdoors; therefore, the indoor absorbed dose depends mainly on the concentration of radioactive substances occurring in the construction materials (Righi and Bruzzi, 2006). If building materials with high natural radioactivity concentration are employed, dose rates indoors will be elevated accordingly.

The assessment of the population exposure due to indoor radiation is very important and therefore knowledge of the concentrations of natural radionuclides in the construction materials is required. Knowledge of radioactivity present in building materials enables the assessment of any possible radiological risks to human health. This information also helps in assessing the level of potential radiological hazard for humans caused by the use of specific building materials (Al-Sulaiti et al., 2011).

Gamma spectroscopy is the most widely used method for measuring these concentrations. The most important natural radionuclides in building materials are ${ }^{226} \mathrm{Ra},{ }^{232} \mathrm{Th}$ and ${ }^{40} \mathrm{~K}$. The external dose rate that is due to these radionuclides and their progeny could reach several hundreds of $\mathrm{nGy} / \mathrm{h}$. 


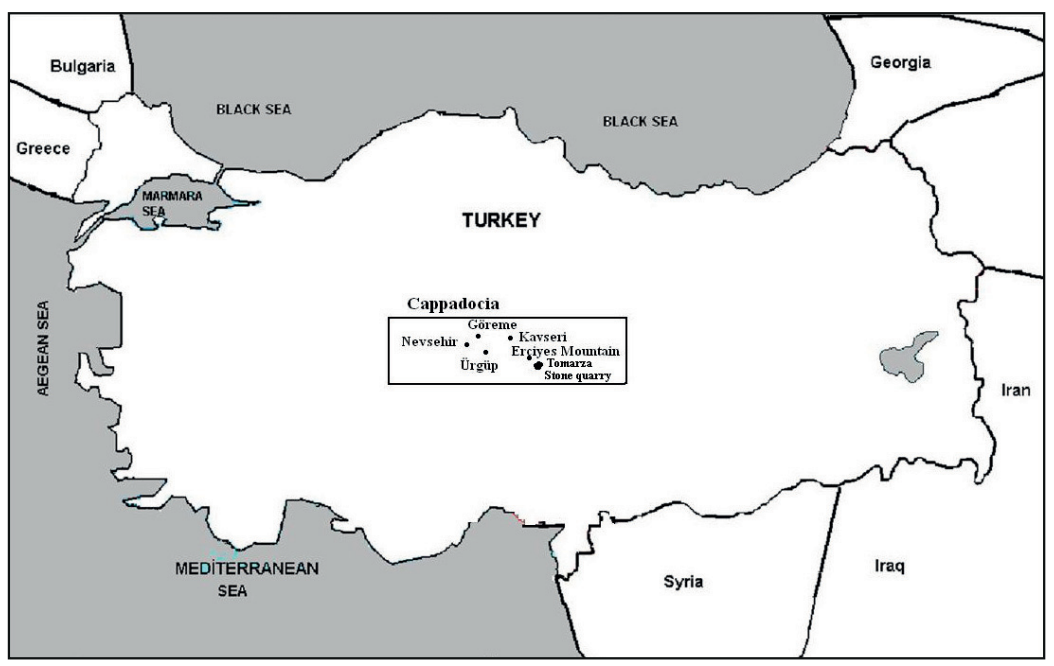

Figure 1 - Sample taking area in Turkey.

The main objectives of this study were to identify chemical contents and to determine natural radionuclide activity concentrations in 6 different colors of volcanic tuff stone samples which are commonly used in building and are decoration materials collected near the extinct Erciyes volcano, and to evaluate the annual effective dose from indoor terrestrial radiation. In addition, the natural gamma radiation coming from terrestrial radionuclides in air was also investigated in the Cappadocia region.

\section{Materials and methods}

Cappadocia, which is unique in the world and is a miraculous natural wonder, is the common name of the area covered by the provinces of Aksaray, Nevsehir, Nigde, Kayseri and Kirsehir in the Central Anatolian region (Fig. 1). The Cappadocia region, as a result of the volcanic eruptions that occurred in Erciyes, Hasandag and Gulludag, forms a large volcanic tuff plateau dissected by the erosion of the Kizilirmak river and wind over tens of thousands of years.

This study was planned to obtain the radioactivity of volcanic stones which are derived from the Cappadocia region and commonly used as building and decoration material in the Cappadocia region and around the world.

Six different colors of volcanic tuff stone samples were collected from a quarry in Tomarza village near the Erciyes extinct volcano (Fig. 1). 
The mineralogical composition and formula of stone samples were determined by a Bruker AXS D8 Advance X-Ray powder diffractometer.

The stone samples were pulverized, dried, homogenized and sieved through 2-mm mesh. The meshed samples were transferred to Marinelli beakers of $1000 \mathrm{ml}$ capacity. The samples were weighed, carefully sealed and stored for more than 30 days to allow secular equilibrium between radium and its decay products (Mollah et al., 1987).

Gamma spectroscopic measurements were performed using a coaxial HPGe detector with $16 \%$ relative efficiency. A detection system containing a Canberra Model 202 Amplifier and a Canberra S-85 Multi-Channel Analyzer with a Model 8087 4K ADC was used for the measurements. The detector was shielded in a 10-cm-thick lead well, internally lined with 2-mm-thick copper and 2-mm-thick cadmium foils. The overall detector resolution (FWHM) of $1.9 \mathrm{keV}$ was obtained for the $1332 \mathrm{keV}$ gamma line of ${ }^{60} \mathrm{Co}$. Energy calibration and relative efficiency calibration of the gamma spectrometer were carried out using ${ }^{109} \mathrm{Cd},{ }^{57} \mathrm{Co},{ }^{113} \mathrm{Sn}$, ${ }^{134} \mathrm{Cs},{ }^{137} \mathrm{Cs},{ }^{88} \mathrm{Y}$ and ${ }^{60} \mathrm{Co}$ calibration sources in $1000-\mathrm{mL}$ Marinelli beakers covering the energy range from 80 to $2500 \mathrm{keV}$. The counting time for each sample, as well as for background, was 50,000 s.

Gamma spectroscopy was used to determine the activities of ${ }^{238} \mathrm{U},{ }^{232} \mathrm{Th},{ }^{40} \mathrm{~K}$ and ${ }^{137} \mathrm{Cs}$. The activity concentrations of ${ }^{232} \mathrm{Th}$ and ${ }^{238} \mathrm{U}$ were calculated assuming secular equilibrium was established with their decay products. For concentrations of ${ }^{232} \mathrm{Th}$ and ${ }^{238} \mathrm{U}$ the following gamma transition lines were used; ${ }^{232}$ Th series: ${ }^{228} \mathrm{Ac}(911 \mathrm{keV}),{ }^{208} \mathrm{Tl}(583.1 \mathrm{keV}) ;{ }^{238} \mathrm{U}$ series: ${ }^{226} \mathrm{Ra}(186.0 \mathrm{keV})$, ${ }^{214} \mathrm{~Pb}(351.9 \mathrm{keV})$ and ${ }^{214} \mathrm{Bi}(609.2 \mathrm{keV})$. For the other radionuclides radioactive equilibrium between ${ }^{214} \mathrm{Bi}$ and ${ }^{226} \mathrm{Ra}$ is assumed. There is a contribution to the intensity of the $186 \mathrm{keV}$ line of about $10 \%$ from the $185 \mathrm{keV}$ line which is the sure basis for the activity of ${ }^{226} \mathrm{Ra}$ (Varinlioglu et al., 1988; Varinlioglu and Kose, 2004). This line was used in this paper. The activity concentration of ${ }^{40} \mathrm{~K}$ was determined from the peak area of the $1460 \mathrm{keV}$ line. The $661.66 \mathrm{keV}$ gamma transition was used to determine the ${ }^{137} \mathrm{Cs}$ concentration.

If radionuclide activity in soil is known, then the corresponding exposure dose rate in air at $1 \mathrm{~m}$ above the ground can be found. The conversion factor of ${ }^{238} \mathrm{U}$, ${ }^{232} \mathrm{Th}$ and ${ }^{40} \mathrm{~K}$ is $0.427,0.662$ and $0.043 \mathrm{nGy} \cdot \mathrm{h}^{-1}$ per Bq. $\mathrm{kg}^{-1}$, respectively (Beck, 1972).

The indoor absorbed gamma dose rate $\left(D_{\text {in }}\right)$ in air was evaluated using data and formulae provided by the EC report (EC, 1999). 
In the EC report, the dose conversion coefficients were calculated for the center of the room. The dimensions of the room are $4 \mathrm{~m} \times 5 \mathrm{~m} \times 2.8 \mathrm{~m}$. The thickness of tiles on all walls and density of the structures are $3 \mathrm{~cm}$ and $2600 \mathrm{~kg} \cdot \mathrm{m}^{-3}$, respectively. These coefficients correspond to $0.12 \mathrm{nGy} \cdot \mathrm{h}^{-1}$ per Bq. $\mathrm{kg}^{-1}$ for ${ }^{226} \mathrm{Ra}$, $0.14 \mathrm{nGy} \cdot \mathrm{h}^{-1}$ per Bq. $\mathrm{kg}^{-1}$ for ${ }^{232} \mathrm{Th}$ and $0.0096 \mathrm{nGy} \cdot \mathrm{h}^{-1}$ per Bq.kg ${ }^{-1}$ for ${ }^{40} \mathrm{~K}$ (EC, 1999; Turhan, 2012):

$$
D_{\text {in }}\left(\mathrm{nGy}^{-1}\right)=0.12 C_{\mathrm{Ra}}+0.14 C_{\mathrm{Th}}+0.0096 C_{\mathrm{K}}
$$

where $C_{\mathrm{Ra}}, C_{\mathrm{Th}}$ and $C_{\mathrm{K}}$ are the activity concentrations of $\mathrm{Ra}$, Th and $\mathrm{K}\left(\mathrm{Bq} \cdot \mathrm{kg}^{-1}\right)$, respectively.

The indoor annual effective dose equivalent $\left(E_{\mathrm{in}}\right)$ was calculated as follows:

$$
E_{\text {in }}(\mathrm{mSv})=D_{\text {in }}\left(\mathrm{nGy} \cdot \mathrm{h}^{-1}\right) \times F_{\mathrm{c}}\left(\mathrm{Sv} \cdot \mathrm{Gy}^{-1}\right) \times T_{\mathrm{E}}\left(\mathrm{h} \cdot \mathrm{y}^{-1}\right) \times 10^{-6}
$$

where $D_{\text {in }}$ is the indoor absorbed gamma dose rate, $F_{\mathrm{c}}$ is the conversion factor of $0.7 \mathrm{~Sv} \mathrm{~Gy}^{-1}$ from the indoor absorbed gamma dose in air to the effective dose received by adults (UNSCEAR, 2000) and $T_{\mathrm{E}}$ is the annual exposure time of 7000 h. $\mathrm{y}^{-1}$, implying that $80 \%$ of time is spent indoors.

Radium equivalent activity $\left(R a_{\mathrm{eq}}\right)$ is used to assess the hazard associated with materials that contain ${ }^{226} \mathrm{Ra},{ }^{232} \mathrm{Th}$ and ${ }^{40} \mathrm{~K}$. This definition is based on the assumption that $1 \mathrm{~Bq} \cdot \mathrm{kg}^{-1}$ of ${ }^{226} \mathrm{Ra}, 0.7 \mathrm{~Bq} \cdot \mathrm{kg}^{-1}$ of ${ }^{232} \mathrm{Th}$ and $13 \mathrm{~Bq} \cdot \mathrm{kg}^{-1}$ of ${ }^{40} \mathrm{~K}$ produce the same gamma dose rate. The $R a_{\text {eq }}$ of the sample (in Bq. $\mathrm{kg}^{-1}$ ) can be determined using the following equation (UNSCEAR, 1988; Al-Sulaiti et al., 2011):

$$
R a_{\mathrm{eq}}=C_{\mathrm{Ra}}+1.43 C_{\mathrm{Th}}+0.077 C_{\mathrm{K}}
$$

The annual external (gamma) index $\left(H_{\mathrm{ex}}\right)$ due to emitted gamma rays of each sample is given by the following equation:

$$
H_{\mathrm{ex}}=\frac{C_{\mathrm{U}}}{370}+\frac{C_{\mathrm{Th}}}{259}+\frac{C_{\mathrm{K}}}{4810} \leq 1
$$

and the internal exposure due to ${ }^{222} \mathrm{Rn}$ and its radioactive progeny is controlled by the internal hazard index, which is given by:

$$
H_{\mathrm{in}}=\frac{C_{\mathrm{U}}}{185}+\frac{C_{\mathrm{Th}}}{259}+\frac{C_{\mathrm{K}}}{4810} \leq 1
$$

where $C_{\mathrm{U}}, C_{\mathrm{Th}}$ and $C_{\mathrm{K}}$ are the activity concentrations of $\mathrm{U}$, Th and $\mathrm{K}$ in Bq. $\mathrm{kg}^{-1}$, respectively. 


\subsection{Gamma index}

In order to assess whether the safety requirements for building materials are being fulfilled, a gamma index proposed by the European Commission (EC, 1999) was used. It is defined as:

$$
I_{\gamma}=\frac{C_{\mathrm{Ra}}}{300}+\frac{C_{\mathrm{Th}}}{200}+\frac{C_{\mathrm{K}}}{3000} \leq 1
$$

where $C_{\mathrm{Ra}}, C_{\mathrm{Th}}$ and $C_{\mathrm{K}}$ are the specific activities of ${ }^{226} \mathrm{Ra},{ }^{232} \mathrm{Th}$ and ${ }^{40} \mathrm{~K}$, respectively (in Bq. $\mathrm{kg}^{-1}$ ). The gamma index should also take into account typical ways and amounts in which the material is used in a building. The limit values depend on the dose criteria, and also on the amount of the material and the manner in which it was used in a building and construction. For material used in bulk amounts, $I_{\gamma} \leq 1$ corresponds to an absorbed gamma dose rate of $1 \mathrm{mSv} \cdot \mathrm{y}^{-1}$ (EC, 1990).

\subsection{Alpha index}

Assessment of the internal hazard originating from the alpha activity of building materials requires calculations of the alpha index, or internal hazard index. The alpha index is calculated by using the following equation:

$$
I_{\alpha}=\frac{C_{\mathrm{Ra}}}{200}
$$

where $C_{\mathrm{Ra}}$ is the specific activity of ${ }^{226} \mathrm{Ra}$. The safe use of materials in building construction requires $I_{\alpha}$ to be less than 1 . This limit corresponds to the design action level for the ${ }^{222} \mathrm{Rn}$ concentration of $200 \mathrm{~Bq} \cdot \mathrm{m}^{-3}$ on an annual average basis for future buildings (EC, 1990; Stojanovska et al., 2010).

\section{Results and discussion}

The average radionuclide activity concentrations in 6 different colors of volcanic stone samples are reported in Tables I and II. Specific activities of ${ }^{226} \mathrm{Ra},{ }^{232} \mathrm{Th}$, ${ }^{40} \mathrm{~K}$ and ${ }^{137} \mathrm{Cs}$ are reported in Bq. $\mathrm{kg}^{-1}$ dry weight (Tab. I). The mean activity concentrations of ${ }^{226} \mathrm{Ra},{ }^{232} \mathrm{Th}$ and ${ }^{40} \mathrm{~K}$ in stone samples are 50.68, 58.63 and $717.55 \mathrm{~Bq} \cdot \mathrm{kg}^{-1}$ respectively. The ${ }^{226} \mathrm{Ra},{ }^{232} \mathrm{Th}$ and ${ }^{40} \mathrm{~K}$ activity concentrations are shown in figure 2 . The mean activity concentrations of ${ }^{238} \mathrm{U}$ and ${ }^{232} \mathrm{Th}$ are 4.2 and 14.4 as ppm and ${ }^{40} \mathrm{~K}$ is $2.4 \mathrm{wt} \%$ (Tab. II).

The light beige-colored tuff stone whose mineralogical composition name is albite intermediate and tridymite has the highest activity concentrations, with 97.2 Bq.kg ${ }^{-1}$, 96.0 Bq. $\mathrm{kg}^{-1}$ and $1036 \mathrm{~Bq} \cdot \mathrm{kg}^{-1}$ for ${ }^{226} \mathrm{Ra},{ }^{232} \mathrm{Th}$ and ${ }^{40} \mathrm{~K}$, 
TABLE I

${ }^{226} \mathrm{Ra},{ }^{232} \mathrm{Th}$ and ${ }^{40} \mathrm{~K}$ activity concentrations of samples as Bq.kg ${ }^{-1}$.

\begin{tabular}{|c|c|c|c|c|c|c|}
\hline Material & $\begin{array}{c}\text { Sample } \\
\text { colors }\end{array}$ & $\begin{array}{c}\text { Mineralogical } \\
\text { composition name }\end{array}$ & ${ }^{226} \mathrm{Ra}(\mathrm{Bq} / \mathrm{kg})$ & ${ }^{232} \mathrm{Th}(\mathrm{Bq} / \mathrm{kg})$ & ${ }^{40} \mathrm{~K}(\mathrm{~Bq} / \mathrm{kg})$ & ${ }^{137} \mathrm{Cs}(\mathrm{Bq} / \mathrm{kg})$ \\
\hline $\mathrm{T} 1$ & yellow & $\begin{array}{l}\text { albite high } \\
\text { tridymite }\end{array}$ & $64.5 \pm 1.6$ & $96.0 \pm 2.3$ & $1033.0 \pm 29.0$ & $<1.1$ \\
\hline $\mathrm{T} 2$ & $\begin{array}{l}\text { dark } \\
\text { gray }\end{array}$ & labradorite & $42.4 \pm 0.8$ & $38.8 \pm 3.6$ & $747.4 \pm 18.6$ & $<0.2$ \\
\hline T3 & $\begin{array}{l}\text { light } \\
\text { gray }\end{array}$ & $\begin{array}{l}\text { andesine } \\
\text { tridymite }\end{array}$ & $50.0 \pm 0.8$ & $61.6 \pm 0.9$ & $813.0 \pm 21.0$ & $<0.3$ \\
\hline $\mathrm{T} 4$ & $\begin{array}{l}\text { light } \\
\text { beige }\end{array}$ & $\begin{array}{c}\text { albite intermediate } \\
\text { tridymite }\end{array}$ & $97.2 \pm 3.0$ & $96.0 \pm 2.2$ & $1036.0 \pm 31.5$ & $<0.4$ \\
\hline T5 & red & andesine & $32.2 \pm 0.6$ & $42.0 \pm 0.7$ & $447.0 \pm 11.7$ & $<0.3$ \\
\hline $\mathrm{T} 6$ & gray & $\begin{array}{l}\text { hatrurite } \\
\text { gypsum }\end{array}$ & $17.8 \pm 0.7$ & $17.4 \pm 1.0$ & $228.9 \pm 8.2$ & $<0.5$ \\
\hline \multicolumn{3}{|c|}{ mean value } & 50.7 & 58.6 & 717.6 & \\
\hline \multicolumn{3}{|c|}{ world average } & 35 & 30 & 400 & \\
\hline
\end{tabular}

TABLE II

${ }^{226} \mathrm{Ra},{ }^{232} \mathrm{Th}$ and ${ }^{40} \mathrm{~K}$ activity concentrations of samples as ppm and $\mathrm{wt} \%$.

\begin{tabular}{cccccc}
\hline Material & Sample colors & $\begin{array}{c}\text { Mineralogical } \\
\text { composition name }\end{array}$ & ${ }^{\mathbf{2 2 6}^{\mathbf{R a}}(\mathbf{p p m})}$ & ${ }^{\mathbf{2 3 2}} \mathbf{T h}(\mathbf{p p m})$ & ${ }^{\mathbf{4 0}} \mathbf{K}(\mathbf{w t} \mathbf{*})$ \\
\hline $\mathrm{T} 1$ & yellow & Albite high tridymite & 5.3 & 23.6 & 3.4 \\
$\mathrm{~T} 2$ & dark gray & labradorite & 3.5 & 9.5 & 2.5 \\
$\mathrm{~T} 3$ & light gray & andesine tridymite & 4.1 & 15 & 2.7 \\
$\mathrm{~T} 4$ & light beige & albite intermediate tridymite & 8 & 23.6 & 3.4 \\
T5 & red & andesine & 2.6 & 10.31 & 1.5 \\
T6 & gray & hatrurite gypsum & 0.6 & 4.3 & 0.8 \\
\hline & & & 4.2 & 14.4 & 2.4 \\
\hline
\end{tabular}

respectively. The highest and lowest activity concentrations of ${ }^{226} \mathrm{Ra},{ }^{232} \mathrm{Th}$ and ${ }^{40} \mathrm{~K}$ were measured in the light beige-colored stone (T4) whose mineralogical composition is albite intermediate and tridymite and in the gray-colored stone (T6) whose mineralogical composition is hatrurite and gypsum, respectively. The worldwide average concentrations of these radionuclides are reported by UNSCEAR (2000) as 35, 30 and $400 \mathrm{~Bq} \cdot \mathrm{kg}^{-1}$ for ${ }^{226} \mathrm{Ra},{ }^{232} \mathrm{Th}$ and ${ }^{40} \mathrm{~K}$, respectively. Our results are higher than the world average.

${ }^{137} \mathrm{Cs}$ was also seen in the samples and analyzed in this study. The anthropogenic radionuclide ${ }^{137} \mathrm{Cs}$ was deposited in the rock of the region presumably as a result of atmospheric fallout of radioactivity following the Chernobyl accident on April 26, 1986, and other previous atmospheric tests of nuclear devices around the world. The ${ }^{137} \mathrm{Cs}$ activity varied from $<0.2$ to $<1.1$ Bq. $\mathrm{kg}^{-1}$ (Tab. I). 


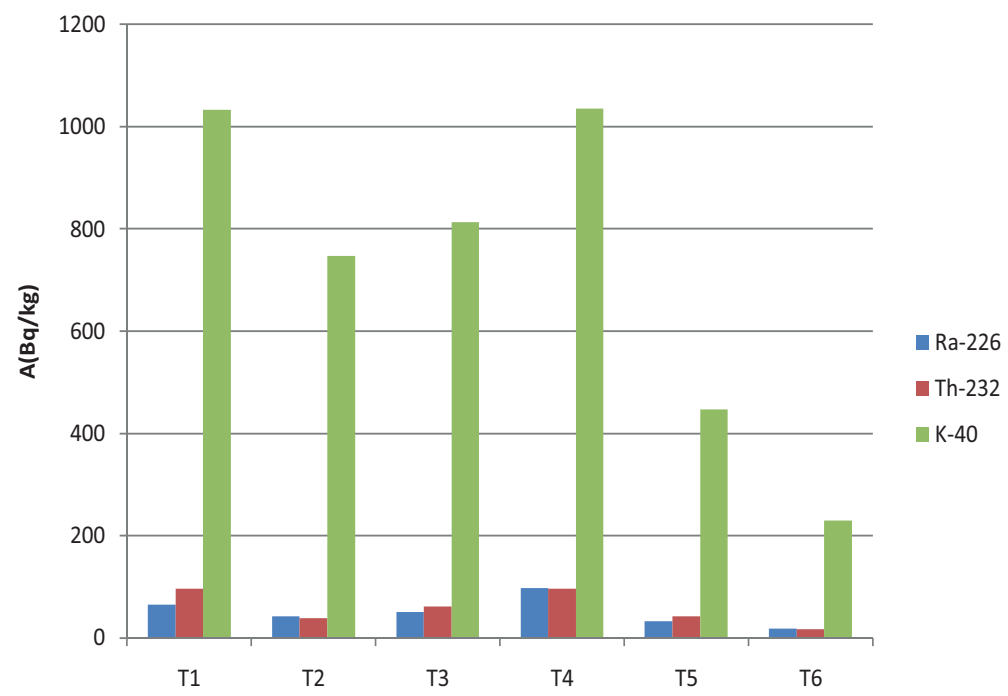

Figure 2 - The natural radioactivity concentrations of the samples.

TABLE III

Calculated absorbed dose rates $\left(D_{\text {in }}\right)$, indoor annual effective doses $\left(E_{\text {in }}\right)$, radium equivalent activity $\left(R a_{\mathrm{eq}}\right)$, internal hazard indices $\left(H_{\mathrm{in}}\right)$, external hazard indices $\left(H_{\mathrm{ex}}\right)$, and alpha and gamma indices for all samples.

\begin{tabular}{|c|c|c|c|c|c|c|c|c|c|}
\hline $\begin{array}{l}\text { Sample } \\
\text { code }\end{array}$ & $\begin{array}{c}\text { Sample } \\
\text { colors }\end{array}$ & $\begin{array}{c}\text { Mineralogica } \\
\text { I composition } \\
\text { name }\end{array}$ & $\underset{(\mathbf{n G y} / \mathbf{h})}{D_{\text {in }}}$ & $\underset{(\mathbf{m S v})}{E_{\text {in }}}$ & $\begin{array}{c}R a_{\mathrm{eq}} \\
(\mathbf{B q} / \mathbf{k g})\end{array}$ & $H_{\text {in }}$ & $\boldsymbol{H}_{\mathrm{ex}}$ & $\begin{array}{r}\text { Gamma } \\
\text { index } I_{\gamma}\end{array}$ & $\begin{array}{c}\text { Alpha } \\
\text { index } I_{\alpha}\end{array}$ \\
\hline $\mathrm{T} 1$ & yellow & $\begin{array}{l}\text { albite high } \\
\text { tridymite }\end{array}$ & 31.1 & 0.15 & 281.3 & 0.9 & 0.8 & 1.0 & 0.3 \\
\hline $\mathrm{T} 2$ & $\begin{array}{l}\text { dark } \\
\text { gray }\end{array}$ & labradorite & 17.6 & 0.09 & 155.4 & 0.5 & 0.4 & 0.6 & 0.2 \\
\hline $\mathrm{T} 3$ & $\begin{array}{l}\text { light } \\
\text { gray }\end{array}$ & $\begin{array}{l}\text { andesine } \\
\text { tridymite }\end{array}$ & 22.4 & 0.11 & 200.7 & 0.6 & 0.5 & 0.8 & 0.3 \\
\hline $\mathrm{T} 4$ & $\begin{array}{l}\text { light } \\
\text { beige }\end{array}$ & $\begin{array}{l}\text { albite } \\
\text { intermediate } \\
\text { tridymite }\end{array}$ & 35.1 & 0.17 & 314.3 & 1.1 & 0.9 & 1.2 & 0.5 \\
\hline T5 & red & andesine & 14.1 & 0.07 & 126.7 & 0.4 & 0.3 & 0.5 & 0.2 \\
\hline T6 & gray & $\begin{array}{l}\text { hatrurite } \\
\text { gypsum }\end{array}$ & 6.8 & 0.03 & 60.3 & 0.2 & 0.2 & 0.2 & 0.1 \\
\hline \multicolumn{3}{|c|}{ mean value } & 21.18 & 0.1 & 189.8 & 0.6 & 0.5 & 0.7 & 0.3 \\
\hline \multicolumn{3}{|c|}{ acceptable level } & 84 & 0.3 & 370 & 1 & 1 & 1 & 1 \\
\hline
\end{tabular}

The calculated values for the indoor annual effective dose $\left(E_{\text {in }}\right)$ ranged from $0.03 \mathrm{mSv}$ to $0.17 \mathrm{mSv}$, with a mean value of $0.1 \mathrm{mSv}$. The results for the indoor annual effective dose $\left(E_{\text {in }}\right)$ are given in Table III. The indoor annual effective dose 


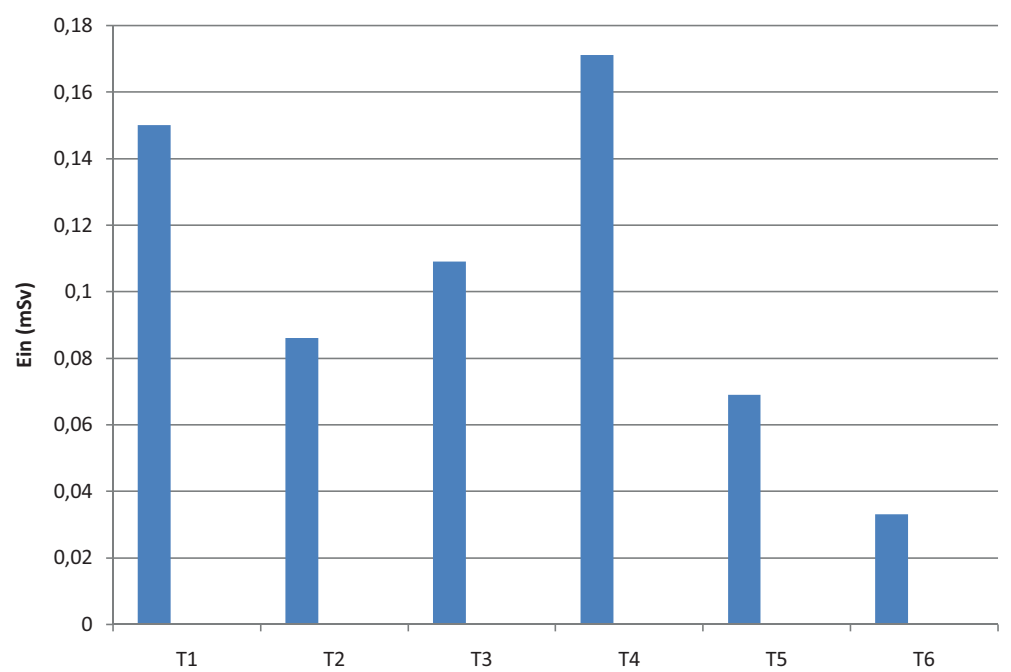

Figure 3 - Indoor annual effective dose equivalent for all samples.

rates for all samples are shown in Figure 3. The indoor annual effective dose rates of the yellow-colored stone whose chemical name is albite high and tridymite and the light beige-colored stone whose chemical name is albite intermediate and tridymite are higher than the other stone samples. It can be seen from Table III that all values of $E_{\text {in }}$ are significantly lower than the exemption dose criterion of $0.3 \mathrm{mSv}$.

The indoor gamma dose rates $\left(I_{\mathrm{in}}\right)$ calculated from the measured activities in stone samples are also given in Table III. The absorbed dose rates in indoor air ranged from $6.8 \mathrm{nGy} \mathrm{h}^{-1}$ to $35.1 \mathrm{nGy}^{-1}$ with a mean of $21.2 \mathrm{nGy} \cdot \mathrm{h}^{-1}$. All calculated indoor absorbed dose rates are lower than the world average. The indoor gamma dose rates due to natural radioactivity for all samples are shown in Figure 4.

The results for radium equivalent activity $\left(R a_{\text {eq }}\right)$ calculated using equation (3) are shown in Table III. These values range from $60 \mathrm{~Bq} \cdot \mathrm{kg}^{-1}$ to $314 \mathrm{~Bq} \cdot \mathrm{kg}^{-1}$ (Tab. III). $R a_{\mathrm{eq}}$ values of all the measured samples were lower than the recommended maximum values $370 \mathrm{~Bq} \cdot \mathrm{kg}^{-1}$ given by the Organization for Economic Cooperation and Development (OECD, 1979) (Fig. 5).

Internal hazard indices $\left(H_{\text {in }}\right)$ range from 0.2 to 1 , with a mean value of 0.6 (Tab. III). Only one sample is higher than 1, the recommended value (Fig. 6). 


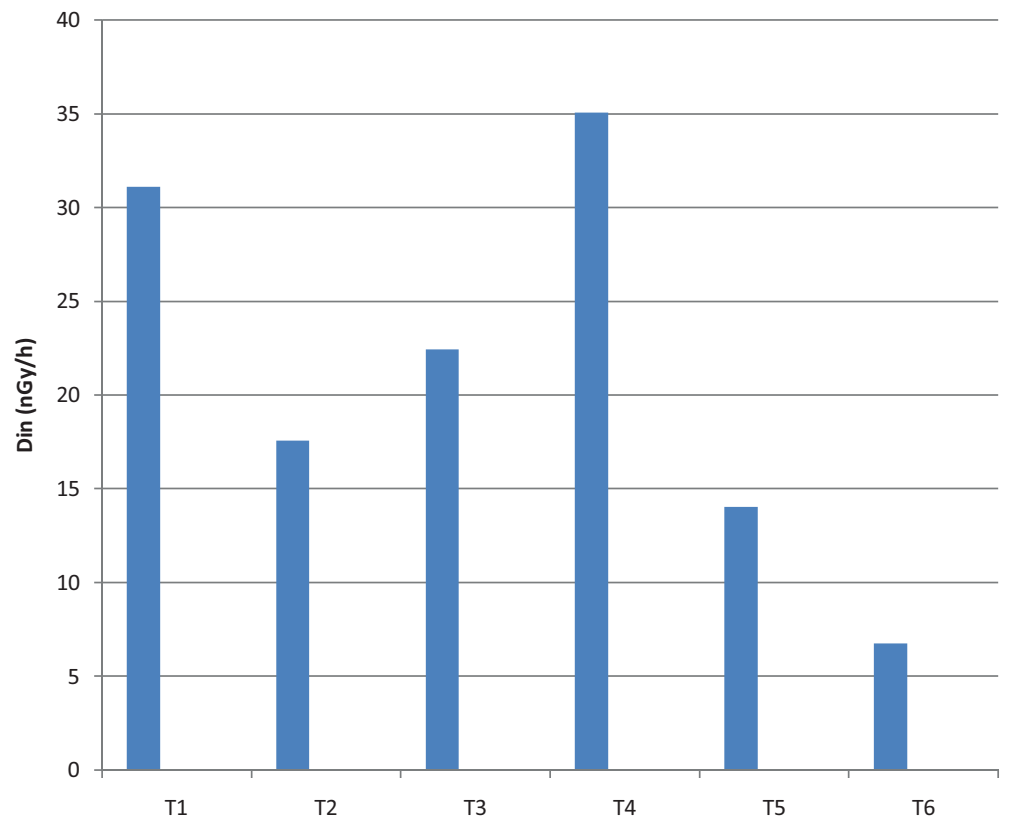

Figure 4 - Indoor absorbed gamma dose rate due to the natural radioactivity for all samples.

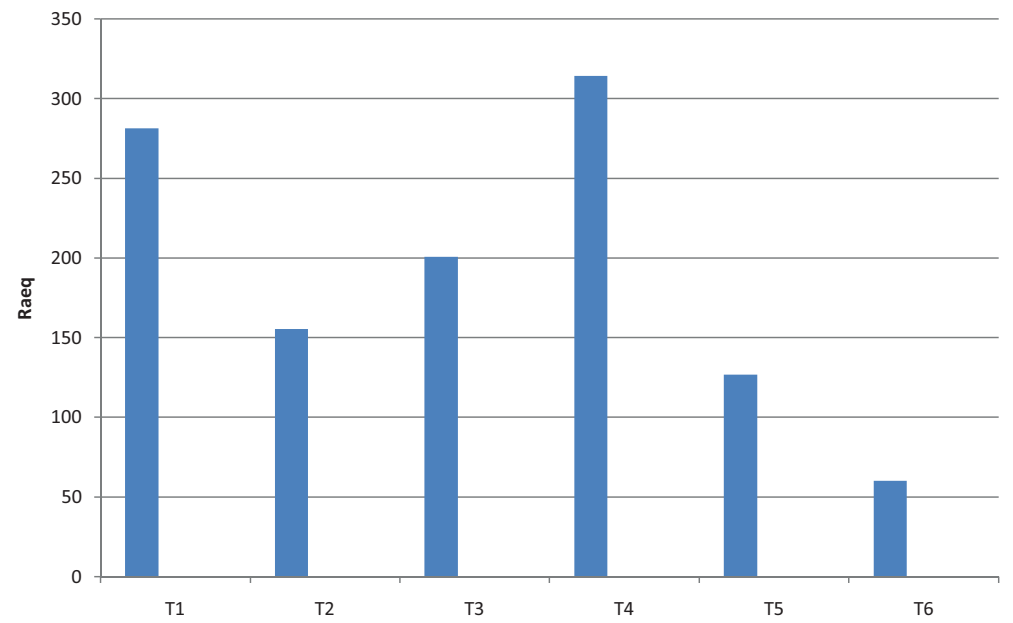

Figure 5 - Radium equivalent activity $\left(R a_{\mathrm{eq}}\right)$ of the samples. 


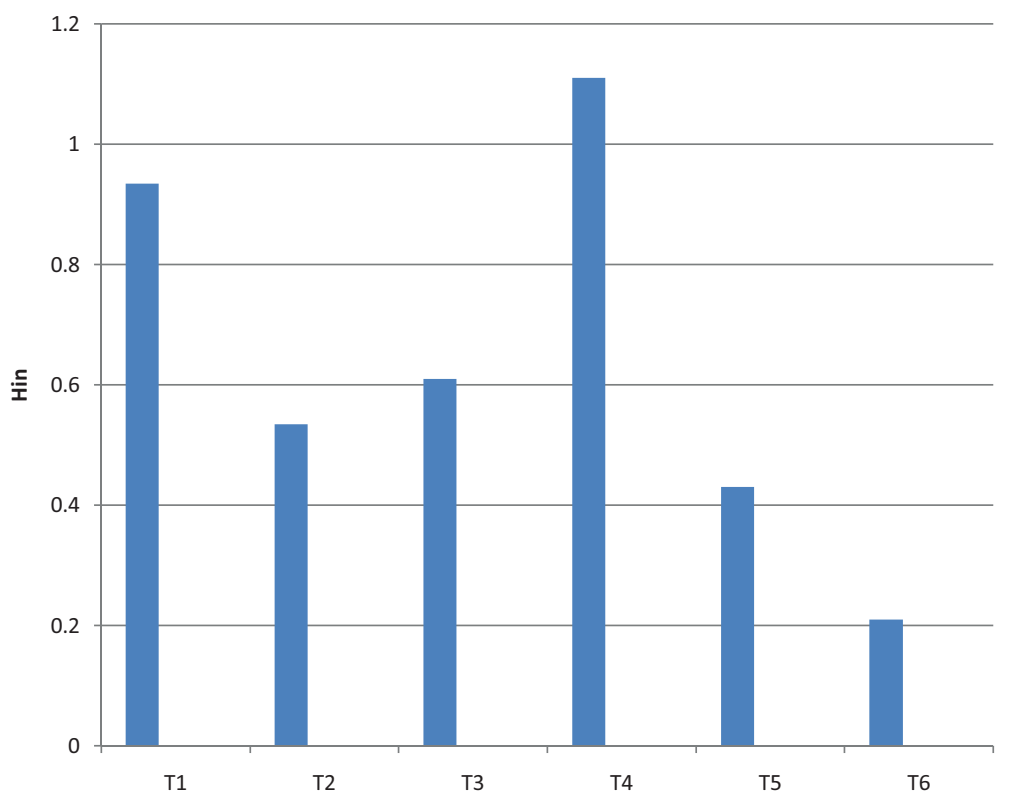

Figure 6 - Internal hazard index of the samples.

Calculated external $\left(H_{\mathrm{ex}}\right)$ and internal hazard index results are shown in Table III. The value of these indices must be less than unity in order for the radiation hazard to be negligible. The calculated $H_{\mathrm{ex}}$ values range from 0.16 to 0.85 , with a mean value of 0.51 . None of the $H_{\mathrm{ex}}$ results exceed the recommended limit equal to1 (Fig. 7).

The calculated gamma $\left(I_{\gamma}\right)$ and alpha $\left(I_{\alpha}\right)$ indices are shown in Table III. The gamma index ranges from 0.2 to 1.2 , with a mean value of 0.7 . The alpha index ranges from 0.1 to 0.5 , with a mean value of $0.25 . I_{\alpha}$ values for all samples studied are below the recommended upper level. The recommended upper limit concentration of ${ }^{226} \mathrm{Ra}$ is $200 \mathrm{~Bq} \cdot \mathrm{kg}^{-1}$, for which $I_{\alpha}=1$.

The mineralogical composition and formula of 6 different colors of volcanic stones are shown in Table IV.

The comparisons of radioactivity with other building materials in Turkey and worldwide are shown in Table $\mathrm{V}$. The radioactivity comparison of volcanic rocks in the same area is shown in Table VI. 


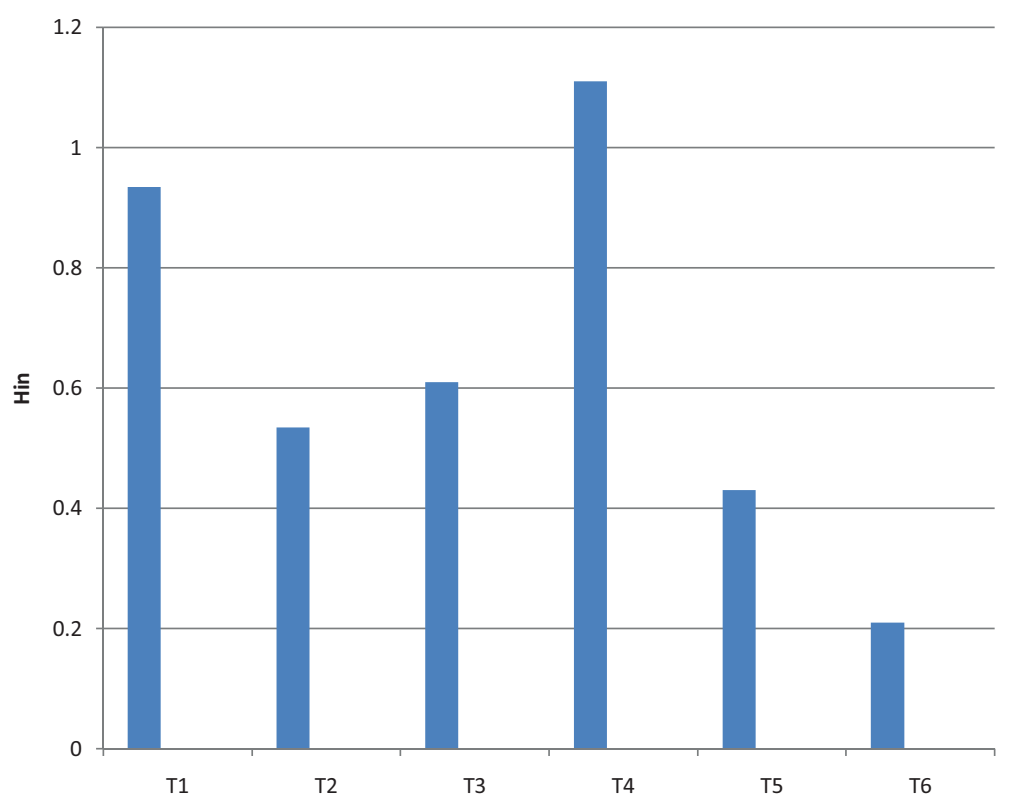

Figure 7 - External hazard index of the samples.

TABLE IV

The mineralogical composition and formula of stone samples.

\begin{tabular}{|c|c|c|}
\hline \multirow{3}{*}{$\begin{array}{c}\text { mineral number } \\
1\end{array}$} & \multicolumn{2}{|c|}{ mineralogical composition } \\
\hline & \multicolumn{2}{|c|}{ T1 } \\
\hline & albite high & $\mathrm{Na}\left(\mathrm{AlSi}_{3} \mathrm{O}_{8}\right)$ \\
\hline 2 & tridymite & $\mathrm{SiO}_{2}$ \\
\hline \multicolumn{3}{|c|}{ T2 } \\
\hline 1 & labradorite & $\mathrm{Ca}_{0.65} \mathrm{Na}_{0.32}\left(\mathrm{Al}_{1.62} \mathrm{Si}_{2.38} \mathrm{O}_{8}\right)$ \\
\hline \multicolumn{3}{|r|}{ 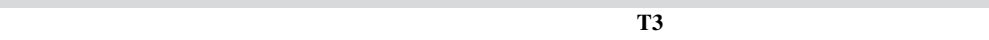 } \\
\hline 1 & andesine & $\mathrm{Na}_{0.499} \mathrm{Ca}_{0.491}\left(\mathrm{Al}_{1.488} \mathrm{Si}_{2.506} \mathrm{O}_{8}\right)$ \\
\hline 2 & tridymite & $\mathrm{SiO}_{2}$ \\
\hline \multicolumn{3}{|c|}{ T4 } \\
\hline 1 & albite intermediate & $\mathrm{Na}_{1.08}\left(\mathrm{Al}_{1.08} \mathrm{Si}_{2.92} \mathrm{O}_{8}\right)$ \\
\hline 2 & tridymite & $\mathrm{SiO}_{2}$ \\
\hline \multicolumn{3}{|c|}{ T5 } \\
\hline 1 & andesine & $\mathrm{Na}_{0.685} \mathrm{Ca}_{0.347} \mathrm{Al}_{1.46} \mathrm{Si}_{2.54} \mathrm{O}_{8}$ \\
\hline \multicolumn{3}{|c|}{ T6 } \\
\hline 1 & hatrurite & $\mathrm{Ca}_{3} \mathrm{SiO}_{5}$ \\
\hline 2 & gypsum & $\mathrm{Ca}\left(\mathrm{SO}_{4}\right)\left(\mathrm{H}_{2} \mathrm{O}\right)_{2}$ \\
\hline
\end{tabular}


TABLE V

The comparison of radioactivity with other building materials in Turkey and worldwide.

\begin{tabular}{|c|c|c|c|c|}
\hline & ${ }^{226} \mathrm{Ra}\left(\mathrm{Bq} \cdot \mathrm{kg}^{-1}\right)$ & ${ }^{232} \mathrm{Th}\left(\mathrm{Bq} \cdot \mathrm{kg}^{-1}\right)$ & ${ }^{40} \mathrm{~K}\left(\mathrm{~Bq} \cdot \mathrm{kg}^{-1}\right)$ & References \\
\hline Turkey (granite) & 88 & 95 & 1055 & Turhan (2012) \\
\hline Turkey (marble) & $10-92$ & $4-122$ & $28-676$ & Cevik et al. (2010) \\
\hline Turkey, Sivrihisar (granite) & 67 & 153 & 1058 & Örgün et al. (2005) \\
\hline Turkey, Ezine (granite) & 175 & 205 & 1172 & Örgün et al. (2007) \\
\hline Red Mud Turkey & 210 & 539,0 & 112,0 & Akinci and Artir (2008) \\
\hline natural building stones & 60 & 60 & 640 & EC (1999) \\
\hline worldwide & 42 & 73 & 1055 & Kitto et al. (2009) \\
\hline $\begin{array}{l}\text { Nevsehir (Turkey) } \\
\text { volcanic tuff stones }\end{array}$ & 50,7 & 58,6 & 717,6 & present work \\
\hline
\end{tabular}

TABLE VI

The comparison of radioactivity with volcanic rocks in the same area.

\begin{tabular}{cccc}
\hline${ }^{238} \mathbf{U}(\mathbf{p p m})$ & ${ }^{\mathbf{2 3 2}} \mathbf{T h}(\mathbf{p p m})$ & ${ }^{\mathbf{4 0}} \mathbf{K}(\mathbf{w t} \mathbf{\%})$ & References \\
\hline 2.3 & 10 & 1.2 & Aydin et al., 2006 \\
4.2 & 14.4 & 2.4 & present work \\
\hline
\end{tabular}

\section{Conclusion}

The specific activities of ${ }^{226} \mathrm{Ra},{ }^{232} \mathrm{Th}$ and ${ }^{40} \mathrm{~K}$ in the different colors of volcanic tuff stones collected from a quarry in Tomarza village, located just near Erciyes extinct volcano, were measured using the gamma spectroscopy technique. The mineralogical composition and formula of stone samples were determined by a Bruker AXS D8 Advance X-Ray powder diffractometer.

The mean activity concentrations of ${ }^{226} \mathrm{Ra},{ }^{232} \mathrm{Th}$ and ${ }^{40} \mathrm{~K}$ in stone samples are $50.68,58.63$ and 717.55 as Bq. $\mathrm{kg}^{-1}$ and respectively. The mean activity concentrations of ${ }^{238} \mathrm{U}$ and ${ }^{232} \mathrm{Th}$ are 4.2 and 14.4 as ppm and ${ }^{40} \mathrm{~K}$ is $2.4 \mathrm{wt} \%$. The average activity concentrations of ${ }^{238} \mathrm{U},{ }^{232} \mathrm{Th}$ and ${ }^{40} \mathrm{~K}$ are 50.7, 58.6 and 717.6 Bq. $\mathrm{kg}^{-1}$, which are higher than the world averages of 35,30 and $400 \mathrm{~Bq} \cdot \mathrm{kg}^{-1}$, respectively.

The absorbed dose rates in indoor air $\left(D_{\text {in }}\right)$ ranged from $6.8 \mathrm{nGy} \cdot \mathrm{h}^{-1}$ to $35.1 \mathrm{nGy} \cdot \mathrm{h}^{-1}$ with a mean of $21.2 \mathrm{nGy} \cdot \mathrm{h}^{-1}$. The average indoor absorbed dose rate $\left(D_{\text {in }}\right)$ for volcanic tuff stones, calculated to be $21.18 \mathrm{nGy} \cdot \mathrm{h}^{-1}$, is lower than the world average of $84 \mathrm{nGy} \cdot \mathrm{h}^{-1}$.

The radium equivalent activity $\left(R a_{\mathrm{eq}}\right)$, the external hazard (gamma) index $\left(H_{\text {ex }}\right)$, internal hazard index $\left(H_{\text {in }}\right)$, gamma index $\left(I_{\gamma}\right)$, alpha index $\left(I_{\alpha}\right)$, indoor annual effective dose equivalent and indoor absorbed gamma dose rate were determined to assess the radiological hazard from volcanic tuff stones in the 
Cappadocia region. The results showed that our results for ${ }^{226} \mathrm{Ra},{ }^{232} \mathrm{Th}$ and ${ }^{40} \mathrm{~K}$ are higher than the world average, which is $35 \mathrm{~Bq} \cdot \mathrm{kg}^{-1}$ for ${ }^{226} \mathrm{Ra}, 30 \mathrm{~Bq} \cdot \mathrm{kg}^{-1}$ for ${ }^{232} \mathrm{Th}$ and $400 \mathrm{~Bq} \cdot \mathrm{kg}^{-1}$ for ${ }^{40} \mathrm{~K}$.

The anthropogenic radionuclide ${ }^{137} \mathrm{Cs}$ activity varied from $<0.2$ to $<1.1 \mathrm{~Bq} \cdot \mathrm{kg}^{-1}$.

The mean value of the indoor annual effective dose $\left(E_{\mathrm{in}}\right)$ was found to be $0.1 \mathrm{mSv}$. The indoor effective dose equivalent of $\mathrm{T}_{1}$ and $\mathrm{T}_{4}$ was found to be higher than the other samples. All values of $E_{\text {in }}$ are significantly lower than the exemption dose criterion of $0.3 \mathrm{mSv}$.

The mean value of radium equivalent activity $\left(R a_{\mathrm{eq}}\right)$ was calculated as $189.78 \mathrm{~Bq} \cdot \mathrm{kg}^{-1}$. This value is lower than the world average, which is $370 \mathrm{~Bq} \cdot \mathrm{kg}^{-1}$ for $R a_{\mathrm{eq}}(\mathrm{OECD}, 1979$; UNSCEAR, 1988).

The internal hazard index's $\left(H_{\text {in }}\right)$ mean value was found to be 0.6 . Only one sample $\left(\mathrm{T}_{4}\right)$ is higher than the recommended value of 1 for $H_{\mathrm{in}}$.

The mean value of the external hazard index was calculated to be 0.51 . No $H_{\mathrm{ex}}$ results exceeded the recommended limit, which is equal to 1 .

A mean value of 0.25 was found for the alpha index $\left(I_{\alpha}\right)$ and 0.7 for the gamma index $\left(I_{\gamma}\right) . I_{\alpha}$ values for all samples are below the recommended upper level. The recommended upper limit concentration of ${ }^{226} \mathrm{Ra}$ is $200 \mathrm{~Bq} \cdot \mathrm{kg}^{-1}$, for which $I_{\alpha}=1$. The gamma indices of $\mathrm{T}_{1}$ and $\mathrm{T}_{4}$ were found to be higher than the recommended value, which is 1 for $I_{\gamma}$.

To the best of our knowledge, this is the first detailed study of radioactivity concentrations and radiation hazard in the different colors of volcanic tuff stones which are commonly used in building and decoration materials.

Acknowledgments. The author thanks the Cekmece Nuclear Research and Training Center - Turkish Atomic Energy Department for their cooperation with carrying out this work. The author also wishes to thank Dr. Gursel Karahan and Dr. Ahmet Varinlioglu for their kind help.

\section{REFERENCES}

Akinci A., Artir R. (2008) Characterization of trace elements and radionuclides and their risk assessment in red mud, Material Characterization 59, 417-421.

Al-Sulaiti H., Alkhomashi N., Al-Dahan N., Al-Dosari M., Bradley D.A., Bukhari S., Matthews M., Regan P.H., Santawamaitre T. (2011) Determination of the natural radioactivity in Qatarian building materials using high - resolution gamma ray spectrometry, NIMA 652, 915-919.

Aydin I., Aydogan M.S., Oksum E., Kocak A. (2006) An attempt to use aerial gamma-ray spectrometry results in petrochemical assessments of the volcanic and plutonic associations of Central Anatolia (Turkey), Geophys. J. Int. 167, 1044-1052. 
Baykara O., Karatepe S., Dogru M. (2011) Assessment of natural radioactivity and radiological hazards in construction materials used in Elazıg, Turkey, Radiat. Meas. 46, 153-158.

Beck H.L. (1972) The Physics of Environmental Radiation Fields. Natural Radiation Environment II, Cohewan. Canada. NF-720805 P2. In: Proceedings of the Second International Symposium on the Natural Radiation Environment.

Cevik U., Damla N., Kobya A.I., Celik A., Kara A. (2010) Radiation dose estimation and mass attenuation coefficients of marble used in Turkey, Ann. Nucl. Energy 37, 1705-1711.

EC (1990) European Commission, recommadation 90/143/Euratom of 21 February on the protection of the public against indoor exposure to radon, Official Journal of Europian Commission L-80 Brussels.

EC (1999) European Commission, Radiation Protection Unit, Radiological Protection Principles Concerning The Natural Radioactivity of Building Materials, Radiat. Prot. 112

Kitto M.E., Haines D.K., Menia T.A. (2009) Assessment of gamma ray emissions from natural and manmade decorative stones, J. Radioanal. Nucl. Chem. 282, 409-413.

Merdanoglu B., Altinsoy N. (2006) Radioactivity concentrations and dose assessment for soil samples from Kestanbul granite area, Turkey, Radiat. Prot. Dosim. 121 (4), 399-405.

Mollah S., Rahman N.M., Kodlus M.A., Husain S.R. (1987) Measurement of high natural background radiation levels by TLD at Cox and Bazar coastal areas in Bangladesh, Radiat. Prot. Dosim. $18(1), 39-41$.

OECD (1979) Exposure to radiation from the natural radioactivity in building materials, Report by a group of experts of the OECD, Nuclear Energy Agency, Paris, France.

Örgün Y., Altinsoy N., Gultekin A.H., Karahan G., Celebi N. (2005) Natural radioactivity levels in granitic plutons and groundwaters in Southeast part of Eskisehir, Turkey, Appl. Radiat. Isotopes $\mathbf{6 3}(2), 267-275$.

Örgün Y., Altinsoy N., Sahin S.Y., Gungor Y., Gultekin A.H., Karahan G., Karacık Z. (2007) Natural and anthropogenic in rocks and beach sands from Ezine region (Canakkale), Western Anatolia, Turkey, Appl. Radiat. Isotopes 65, 739-747.

Righi S., Bruzzi L. (2006) Natural radioactivity and radon exhalation in building materials used in Italian dwellings, J. Environ. Radioactivity 88, 158-170.

Stojanovska Z., Nedelkovski D., Ristova M. (2010) Natural radioactivity and human exposure by raw materials and end product from cement industry used as building materials, Radiat. Meas. $\mathbf{4 5 ,}$ 969-972.

Stoulos S., Manolopoulou M., Papastefanou C. (2003) Assessment of natural radiation exposure and radon exhalation from building materials in Greece, J. Environ. Radioactivity 69 (3), 225-240.

Turhan S. (2008) Assessment of the natural radioactivity and radiological hazards in Turkish cement and its raw materials, J. Environ. Radioactivity 99, 404-414.

Turhan S. (2012) Estimation of possible radiological hazards from natural radioactivity in commercially-utilized ornamental and countertops granite tiles, Ann. Nucl. Energy 44, 34-39.

UNSCEAR (1988) United Nations Scientific Committee on the Effects of Atomic Radiation, Sources and Biological Effects of Ionizing Radiation, United Nations, New York.

UNSCEAR (2000) United Nations Scientific Committee on the Effects of Atomic Radiation, Sources and Biological Effects of Ionizing Radiation, United Nations, New York.

Varinlioglu A., Kose A. (2004) Determination of natural and artificial radionuclide levels in soils of western and southern coastal area of Turkey, Water, Air \& Soil Pollution 164, 401-407.

Varinlioglu A., Akyuz T., Kose A. (1988) The radioactivity measurement of Turkish lignites, $J$. Environ. Radioactivity 41 (3), 381-387. 